\title{
C - reactive protein and urinary tract infection due to Gram-negative bacteria in a pediatric population at a tertiary hospital, Mwanza, Tanzania
}

\author{
Martha F Mushi ${ }^{1}$, Vaileth G Alex ${ }^{1}$, Mwanaisha Seugendo ${ }^{2}$, Vitus Silago ${ }^{1}$, Stephen E Mshana ${ }^{1}$
}

1. Department of Microbiology/Immunology, Weill Bugando School of Medicine, Catholic University of Health and Allied Science

2. Department of Pediatric and Child Health, Weill Bugando School of Medicine, Catholic University of Health and child health

\section{Emails:}

MFM: mushimartha@gmail.com; VGA:alexvaileth22@gmail.com; MS: seugendomwanaisha@yahoo.com; VS:vsilago.silago2@gmail.com; SEM: stephen72mshana@gmail.com

\begin{abstract}
Introduction: Gram-negative bacteria are the major cause of urinary tract infections (UTI) in children. There is limited data on UTI systemic response as measured using C-reactive protein (CRP). Here, we report the association of CRP and UTI among children attending the Bugando Medical Centre, Mwanza, Tanzania.

Methods: A cross-sectional study was conducted between May and July 2017. Urine and blood were collected and processed within an hour of collection. Data were analyzed using STATA version 13.

Results: Of 250 enrolled children, 76(30.4\%) had significant bacteriuria with 56(22.4\%, 95\%CI; 11.5-33.3) having gram-negative bacteria infection. There was dual growth of gram-negative bacteria in 3 patients. Escherichia coli $(32.2 \%, 19 / 59)$ was the most frequently pathogen detected. A total of $88 / 250(35.2 \%)$ children had positive CRP on qualitative assay. By multinomial logistic regression, positive $\mathrm{CRP}(\mathrm{RRR}=4.02,95 \% \mathrm{CI}: 2.1-7.7, \mathrm{P}<0.001)$ and age $\leq 2$ years $(\mathrm{RRR}=2.4,95 \% \mathrm{CI}$ : 1.23-4.73, P<0.01) significantly predicted the presence of significant bacteriuria due to gram-negative enteric bacteria.

Conclusion: C-reactive protein was significantly positive among children with UTI due to gram-negative bacteria and those with fever. In children with age $\leq 2$ years, positive CRP indicates UTI due to gram-negative enteric bacteria.

Keywords: C - reactive protein, urinary tract infection, Gram-negative bacteria, Mwanza, Tanzania.

DOI: https://dx.doi.org/10.4314/ahs.v19i4.45

Cite as: Mushi MF, Alex VG, Seugendo M, Silago V, Mshana SE. C - reactive protein and urinary tract infection due to Gram-negative bacteria in a pediatric population at a tertiary hospital, Mwanza, Tanzania. Afri Health Sci.2019;19(4):3217-3224. https:// dx.doi. org/10.4314/ahs.v19i4.45
\end{abstract}

\section{Background}

Urinary tract infection (UTI) have been noted as the commonest cause of bacterial infection among children under five years of age in low-income countries ${ }^{1-3}$. It is documented that $91 \%$ of bacteria causing UTI in chil-

\section{Corresponding author:}

Martha F Mushi,

Department of microbiology/Immunology

Weill Bugando School of Medicine

Box 1464, Mwanza Tanzania

Email: mushimartha@gmail.com dren are gram negative bacteria ${ }^{2-4}$. This observation is of public health concern due to the increased antimicrobial resistance associated with gram negative bacteria. In the city of Mwanza, Tanzania, it was reported that more than $37 \%$ of gram negative bacteria causing UTI in children were producing extended spectrum beta lactamases $(\mathrm{ESBL})^{1-3}$. In addition, ESBL producing gram negative bacteria had co-resistance to trimethoprim/sulfamethoxazole, fluoroquinolones and aminoglycosides ${ }^{5-8}$, which further complicates the management of infection caused by these pathogens. In children, if UTI is not properly and adequately treated can lead to complications like renal scaring ${ }^{9,10}$, the leading cause of end-stage renal disease

(C) 2019 Mushi et al. Licensee African Health Sciences. This is an Open Access article distributed under the terms of the Creative commons Attribution License (https://creativecommons.org/licenses/BY/4.0), which permits unrestricted use, distribution, and reproduction in any medium, provided the original work is properly cited. 
in this population ${ }^{1}$. Therefore, a rapid test to indicate the presence of pathogens is highly needed especially in the place where there are no culture services.

The recommended diagnosis of UTI is quantitative urine culture, nevertheless this technique is expensive, take long time and not commonly available in many health facilities in resource limited settings. The $\mathrm{C}$-reactive protein(CRP) often becomes elevated within few hours after tissue injury or the start of an infection ${ }^{11,12}$. In healthy individuals, CRP is normally present in a very low concentration of less than $6 \mathrm{mg} / \mathrm{l}^{11,13}$. Elevated CRP has been used as the predictor of inflammations among patients with infections including neonatal sepsis ${ }^{14}$, fungal infections ${ }^{15}$ and pelvic inflammatory diseases ${ }^{16}$.

Previous studies done in Europe and India reported a significant high CRP among patients with UTI than those without UTI ${ }^{17-19}$. Increase in CRP has commonly being detected in UTI caused by Escherichia coli, Protens spp., Klebsiella pneumoniae, Staphylococcus aureus and others ${ }^{17}$. In addition, CRP had been suggested as the marker for the treatment progress ${ }^{20,21}$. However, the association of the CRP and UTI caused by gram negative bacteria among children with signs and symptoms of UTI has never being documented in many low-income settings. Therefore, this study was done to determine the association of C-reactive protein and UTI caused by gram negative bacteria among children attending the Bugando Medical Centre. The qualitative CRP assay is inexpensive and can be adopted in many settings to guide appropriate antibiotic treatment in patients with suspected bacterial infections including UTI.

\section{Methodology}

This cross-sectional hospital based study was conducted from May to July 2017 at pediatric out patients' clinic and pediatric wards of the Bugando Medical Centre (BMC). $\mathrm{BMC}$ is a tertiary and teaching hospital with a bed capacity of 1000. BMC serve about 13 million people from six regions. This study included children with presumptive diagnosis of UTI admitted or attending pediatric clinic at BMC. In this study children with either fever, painful micturition or pus in urine were presumptively diagnosed with UTI. To reduce CRP false positive results as indicated in the manufacturer guidelines; children with hepatitis and those who were HIV positive were excluded.

\section{Data and sample collection}

A clean catch method for obtaining a midstream urine was used to collect urine sample from children above 2 years of age $e^{22,23}$. For children below two years of age and in all children who have not been pre-trained on toileting supra-pubic aspiration was aseptically done $e^{3,24}$. Urine samples were collected in clean sterile container (HiMedia Laboratories. Pvt. Ltd, India) and transported to the microbiology laboratory for processing within an hour of sample collection. Standard quantitative urine culture was done on Cysteine lactose electrolyte deficient (CLED), MacConkey and blood agar plates (Oxoid, UK) ${ }^{3}$. Plates were aerobically incubated at $37^{\circ} \mathrm{c}$ for $18-24$ hours.

The presence of at least $10^{5} \mathrm{CFU} / \mathrm{ml}$ for midstream urine and any growth for supra-pubic urine was defined as significant bacteriuria. Bacterial specie identifications were done using in house biochemical test ${ }^{22,25}$. Antibiotic susceptibility test was performed using Kirby-Bauer disc diffusion method following the guidelines laid down by the Clinical Laboratory Standard Institute(CLSI ${ }^{26}$. E. coli ATCC 25922 and Staphylococcus aureus ATCC 25923 were used for quality control.

Furthermore, $2 \mathrm{ML}$ of venous blood was collected and placed in to the plain vacutainer tube (BD Vacutainer, Nairobi Kenya). Qualitative C-reactive protein assay was performed following manufacturer instructions (Diagnostics Euromedi Equip UK). Presence of agglutinations similar with a positive control was considered as positive C-reactive protein (i.e greater than $6 \mathrm{mg} / \mathrm{dl}$ ).

\section{Data management and analysis}

Data entry was done using Microsoft excel 2007 cleaned and transferred to STATA version 13(College station, Texas) for analysis. Categorical variables were presented as proportions while continuous variables were summarized using median (Inter quartile range). Chi square or Fisher's exact were used to establish statistical differences in proportions while logistic regression analysis was used to establish strength of association between CRP and the age, sex, gram-negative culture results, diarrhea and fever. Multivariate logistic was performed for all factors with $\mathrm{P}$ less than 0.2 controlled by age and sex to establish independent predictors of elevated CRP levels. Furthermore, multinomial logistic regression analysis was done using gram reaction (no significant bacteriuria, gram positive significant bacteriuria and gram negative significant bacteriuria) as the outcome. Statistical significance was set at 
$95 \%$ confidence interval with a $\mathrm{p}$ value of less than 0.05 as significant.

\section{Results}

Demographic Characteristics of Study population

A total of 250 children were enrolled in the study, their median age (IQR) was 3(1-4.5) years. The slightly majority of the study participants were male 142(56.8\%) and $128(51.2 \%$ ) had fever (Table 1). Failure to gain weight was observed in $6(2.4 \%)$ children while $29(11.6 \%)$ had diarrhoea.

Table 1: Demographic features and clinical data representing 250 pediatric patients at BMC.

\begin{tabular}{|l|l|l|}
\hline Children characteristics & Frequency & \multicolumn{1}{l|}{ Percentage (\%) } \\
\hline Median age* & \multicolumn{2}{|l|}{ (IQR;1-4.5) } \\
\hline Sex & \multicolumn{2}{|l|}{} \\
\hline Male & 142 & 56.8 \\
\hline Female & 108 & 43.2 \\
\hline Diarrhea & & \\
\hline Yes & 29 & 11.6 \\
\hline No & 221 & 88.4 \\
\hline Fever & & \\
\hline Yes & 128 & 51.2 \\
\hline No & 122 & 48.8 \\
\hline Cough & & \\
\hline Yes & 58 & 23.20 \\
\hline No & 192 & 76.80 \\
\hline Body swelling & & \\
\hline Yes & 46 & 18.40 \\
\hline No & 204 & 81.60 \\
\hline Failure to gain weight & & \\
\hline Yes & 6 & 2.40 \\
\hline No & 244 & 97.60 \\
\hline Weight loss & & \\
\hline Yes & 38 & 15.26 \\
\hline No & 211 & 84.74 \\
\hline Oral thrush & 3 & 1.2 \\
\hline Yes & 247 & 98.8 \\
\hline No & & \\
\hline
\end{tabular}

Median age and interquatile range are presented

Culture results and antibiotic susceptibility pattern Of 250 enrolled children, 76(30.4\%, 95\%CI 24.6-36.1) had significant bacteriuria with a total of $56(22.4 \%$, 95\%CI; 11.5-33.3) children having significant bacteriuria due to gram negative bacteria; making $73.6 \%$ of UTI cases being due to gram negative enteric bacteria. Three children had significant bacteriuria of dual gram negative pathogens. Escherichia coli, Klebsiella oxytoca and K.pneumoniae accounted for 32.2\%(19/59), 18.6\%(11/59) and $15.3 \%(9 / 59)$ of isolates, respectively. Two gram negative bacteria $(3.4 \%)$ could not be identified (Table 2). Other uropathogens detected include: Candida spp: 13.2\%(10/76), Staphylococcus aureus: $9.2 \%(7 / 76)$ and Streptococcus pyogenes: $3.9 \%(3 / 76)$.

The isolated gram negative bacteria were highly resistant to ampicillin (94\%) and amoxicillin/clavulanic acid (82\%). Regarding the resistance to third generation cephalosporins, 39\% and 33\% of enteric gram negative isolates were resistant to ceftriaxone and ceftazidime, respectively (Figure 1). All gram negative bacteria detected were 100\% sensitive to meropenem. 
Table 2: Distribution of the gram-negative bacteria isolates causing UTI

\begin{tabular}{|l|r|r|}
\hline Gram negative bacteria Isolate & Frequency & \multicolumn{1}{l|}{ Percentage (\%) } \\
\hline Escherichia coli & 19 & 32.2 \\
\hline Klebsiella oxytoca & 11 & 18.6 \\
\hline Klebsiella pneumonia & 9 & 15.3 \\
\hline Enterobacter aerogenes & 8 & 13.6 \\
\hline Acinetobacter spp. & 4 & 6.8 \\
\hline Citrobacter freundii & 3 & 5.1 \\
\hline Unidentified gram negative & 2 & 3.4 \\
\hline Proteus mirabilis & 1 & 1.7 \\
\hline Pseudomonas aureginosa & 1 & 1.7 \\
\hline Morganella morganii & 1 & 1.7 \\
\hline TOTAL & 59 & 100 \\
\hline
\end{tabular}

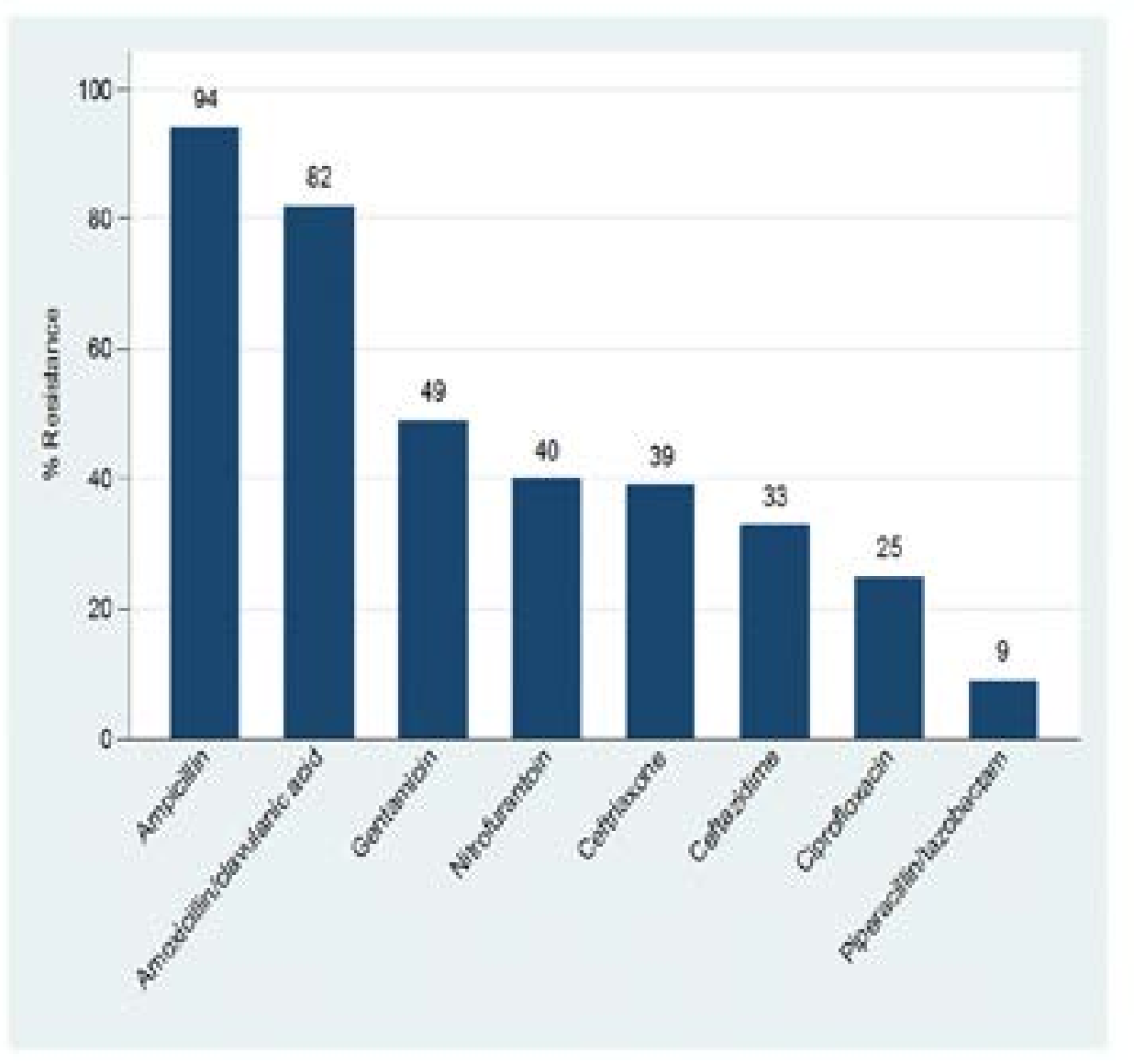

Figure 1: Antibiotic resistant patterns of gram negative bacteria isolates causing UTI among children at BMC.

\section{Qualitative C-reactive protein assay}

A total of $88(35.2 \%)$ children had positive results on qualitative CRP assay. Out of 128 children with fever, $55(55.5 \%)$ had positive results on qualitative CRP assay compared to $17 / 122(13.9 \%)$ of children with no fever $(\mathrm{P}<0.001)$. Positive CRP was significantly more in children with UTI due to gram negative bacteria than in children with gram positive UTI $(30 \%)$ and those with no significant bacteriuria (28.2\%), $\mathrm{P}<0.001$, Table 3 . 
Table 3: Factors associated with positive C-reactive protein among 250 children with UTI at BMC.

\begin{tabular}{|c|c|c|c|c|c|}
\hline \multirow[b]{2}{*}{ Variables } & \multicolumn{3}{|c|}{ Univariate analysis } & \multicolumn{2}{|c|}{ Multivariate analysis } \\
\hline & CRP (+ve) Median/n (\%) & $\mathrm{OR}(95 \% ; \mathrm{Cl})$ & $P$ value & $\mathrm{OR}(95 \% ; \mathrm{Cl})$ & P value \\
\hline Age & 3(IQR:1-4.5) & $0.98(0.89-1.08)$ & 0.788 & & \\
\hline \multicolumn{6}{|l|}{ Sex } \\
\hline Male (142) & $49(34.5)$ & 1 & & & \\
\hline Female (108) & $39(36.1)$ & $1.07(0.63-1.81)$ & 0.793 & & \\
\hline \multicolumn{6}{|l|}{ Fever } \\
\hline No (122) & $17(13.9)$ & 1 & & & \\
\hline Yes (128) & $71(55.5)$ & $7.69(4.1414 .29)$ & $<0.001$ & $7.57(3.94-14.55)$ & $<0.001$ \\
\hline \multicolumn{6}{|l|}{ Diarrhea } \\
\hline No (221) & $74(33.5)$ & 1 & & & \\
\hline Yes (29) & $14(48.3)$ & $1.85(0.84-4.04)$ & 0.121 & $1.44(0.58-3.42)$ & 0.444 \\
\hline \multicolumn{6}{|l|}{ Bacteriuria } \\
\hline $\begin{array}{l}\text { Culture negative } \\
(174)\end{array}$ & $49(28.2)$ & 1 & & & \\
\hline Gram Positive (20) & $6(30.0)$ & $1.1(0.39-3.00)$ & 0.863 & $1.54(0.49-4.78)$ & 0.452 \\
\hline Gram negative (56) & $33(58.9)$ & $3.66(1.96-6.84)$ & $<0.001$ & $3.54(1.73-7.22)$ & 0.001 \\
\hline
\end{tabular}

By multivariate logistic regression analysis, children with fever (OR 7.57, 95\% CI: 3.94-14.55, P<0.001) and those with UTI due to gram negative bacteria (OR 3.54, 95\% CI: 1.73-7.22, $\mathrm{P}=0.001)$ were more likely to have positive CRP results (Table 3). By multinomial logistic regression analysis was done, no bacteria was used as base and other outcomes being gram positive significant bacteriuria and gram negative significant bacteriuria, factors found to independently predict gram negative significant bacteriuria were positive CRP $(\mathrm{RRR}=4.02,95 \% \mathrm{CI}: 2.1-7.7$, $\mathrm{P}<0.001)$ and age $\leq 2$ years $(\mathrm{RRR}=2.4,95 \% \mathrm{CI}: 1.23-4.73$, $\mathrm{P}<0.01)$. Fever was not subjected to multinomial logistic regression due to its strong collinearity with positive CRP.

\section{Discussion}

The prevalence of significant bacteriuria due to gram negative enteric bacteria among children with presumptive diagnosis of UTI in the current study was $22.4 \%$. This is similar to the results from the previous study conducted 6 years ago in the same settings which observed the prevalence of enteric gram negative bacteria UTI to be $20.3 \% 0^{1,2}$. The current results indicate that the contribution of gram negative in causing UTI at BMC has remained relative the same. Nevertheless, the observed prevalence of gram negative enteric bacteria causing UTI in children is slightly lower than $29.3 \%$ and $39.7 \%$ reported from Kenya and Uganda ${ }^{27,28}$, respectively. The ob- served difference could be explained by the differences in study population, a significant proportion of children in studies from Kenya and Uganda had co-morbidities such as malnutrition and HIV. Co-morbidities have been found to pedispose to infections such as $\mathrm{UTI}^{1,27}$. In the current study out of six children who failed to gain weight only 1 had significant bacteriuria, the number is too low for any statistical test therefore no conclusion could be made. Escherichia coli and Klebsiella spp., have been reported in previous studies ${ }^{29-31}$ to contribute more than three quarter of the bacteria causing UTI in children of all ages. This was confirmed in the present study whereby these were predominant pathogens causing UTI. This can partly be explained by the fact that Escherichia coli and Klebsiella spp. are among the normal flora in the gastrointestinal tract (GIT), hence can easily cause UTI due to the close proximity of GIT and urinary tract.

As it was reported previous by other studies in the same settings ${ }^{1-3,5}$, bacteria detected in the current study were highly resistant to ampicillin and amoxicillin/clavulanic acid. This could be explained by the fact that these antimicrobial agents are inappropriately used to treat respiratory infections among children in Tanzania, hence increase the chance of pathogens to develop resistance against them ${ }^{3}$. Similar findings were reported elsewhere ${ }^{32,33}$ which necessity the need of increasing effort in promoting ap- 
propriate antimicrobial use through antimicrobial stewardship programmes.

Early detection of bacterial infection is crucial for the proper management of patients to reduce the associated morbidity and mortality. In the current study about one third of the enrolled children had positive CRP (i.e elevated CRP). CRP has been found to be a more sensitive maker in predicting gram negative bacterial infections than gram positive bacterial infections in children ${ }^{14}$. This has been confirmed in the current study whereby patient with gram negative bacterial infections had 3.54 times higher odds of having positive CRP results with positive CRP being an independent predictor of presence of gram negative significant bacteriuria. These findings are similar to previous studies reported in Turkey, England, Iran and US among children with UTI ${ }^{20,29,34,35}$.

As it was reported previously from other studies ${ }^{13,36}$; this study has confirmed that, fever strongly predicts positive CRP results. This may be due to presence of pro-inflammatory cytokines like interleukin 1 and interleukin 6 that signal the liver to produce high concentration of $\mathrm{CRP}^{37}$. Therefore, in the place with limited diagnostic facilities positive qualitative CRP assay in children with fever and other symptoms and signs of UTI can be used to predict the possible group of pathogens which is important for early appropriate antibiotic treatment. Early appropriate initiation of the right antibiotics has been found to reduce morbidity such as renal scarring and mortality associated with UTI.

\section{Limitation}

Failure to do serial dilution of CRP and possibility of having other undiagnosed conditions might affect the result of this study.

\section{Conclusion and recommendations}

Qualitative CRP assay is mostly likely to be positive in children with fever and can predict the significant bacteriuria of gram negative bacteria especially in young children. In place with limited culture services, clinicians should start appropriate treatment for gram negative bacteria in young children $(\leq 2$ years $)$ with presumptive diagnosis of UTI and positive qualitative CRP assay in order to reduce UTI associated morbidity and mortality. Further studies to evaluate the effectiveness of CRP in monitoring treat- ment of UTI and establish cutoff value of quantitative CRP in the diagnosis of gram negative enteric bacteria UTI are warranted.

\section{Declaration}

\section{Ethical approval and consent to participate}

The protocol for conducting the study was approved by the Joint Catholic University of Health and Allied Sciences/Bugando Medical Centre (CUHAS/BMC) research ethics and review committee (CREC) with certificate no: CREC/274/2017. Consent to participate was obtained from guardians/parents.

\section{Consent for publication}

Not applicable.

\section{Availability of data and material}

The data is available upon request and the request should be made to the Director of research and Innovation Catholic University of Health and allied Sciences.

\section{Competing interest}

All authors have declared that they have no competing interest in publishing this work.

\section{Funding}

This study was supported by the research grant from Department of Microbiology and Immunology of Catholic University of Health and Allied Sciences to VGA.

\section{Authors' contributions}

MFM and SEM designed the work. VGA and MS participated in the collection of data and specimens. MFM, SEM, VGA and VS performed laboratory investigations. MFM and SEM analyzed and, interpreted the data. MFM wrote the first draft of the manuscript which was critically reviewed by SEM. All authors read and approved the final version of the manuscript.

\section{Acknowledgement.}

Authors would like to acknowledge the support provided by Pediatric and Child health of the Bugando Medical Centre and Microbiology and Immunology department of Catholic University of Health and Allied Sciences. We thank all parents/guardians for allowing their children to participate in the study. 


\section{References}

1. Ahmed M, Moremi N, Mirambo MM, Hokororo A, Mushi MF, Seni J, Kamugisha E, Mshana SE: Multi-resistant gram negative enteric bacteria causing urinary tract infection among malnourished underfives admitted at a tertiary hospital, northwestern, Tanzania. Italian Journal of Ppediatrics 2015, 41(1):44.

2. Msaki BP, Mshana SE, Hokororo A, Mazigo HD, Morona D: Prevalence and predictors of urinary tract infection and severe malaria among febrile children attending Makongoro health centre in Mwanza city, North-Western Tanzania. Archives of Public Health 2012, 70(1):4.

3. Festo E, Kidenya BR, Hokororo A, Mshana SE: Predictors of urinary tract infection among febrile children attending at Bugando Medical Centre Northwestern, Tanzania. Archives of Clinical Microbiology 2011.

4. Weinstein RA, Gaynes R, Edwards JR: Overview of nosocomial infections caused by gram-negative bacilli. Clinical Infectious Diseases 2005, 41(6):848-854.

5. Christopher A, Mshana SE, Kidenya BR, Hokororo A, Morona D: Bacteremia and resistant gram-negative pathogens among under-fives in Tanzania. Italian Journal of Pediatrics 2013, 39(1):27.

6. Blomberg B, Manji KP, Urassa WK, Tamim BS, Mwakagile DS, Jureen R, Msangi V, Tellevik MG, Holberg-Petersen M, Harthug S: Antimicrobial resistance predicts death in Tanzanian children with bloodstream infections: a prospective cohort study. BMC Infectious Diseases 2007, 7(1):43.

7. Cosgrove SE: The relationship between antimicrobial resistance and patient outcomes: mortality, length of hospital stay, and health care costs. Clinical Infectious Diseases 2006, 42(Supplement_2):S82-S89.

8. Ramphal R, > PGA: Extended-spectrum $\beta$-lactamases and clinical outcomes: current data. Clinical Infectious Diseases 2006, 42(Supplement_4):S164-S172.

9. Holland NH, Jackson EC, Kazee M, Conrad GR, Ryo UY: Relation of urinary tract infection and vesicoureteral reflux to scars: follow-up of thirty-eight patients. The Journal of Pediatrics 1990, 116(5):S65-S71.

10. Rushton HG, Majd M, Jantausch B, Wiedermann BL, Belman AB: Renal scarring following reflux and nonreflux pyelonephritis in children: evaluation with $99 \mathrm{~m}$ technetium-dimercaptosuccinic acid scintigraphy. The Journal of Urology 1992, 147(5):1327-1332.

11. Young B, Gleeson M, Cripps AW: C-reactive protein: a critical review. Pathology 1991, 23(2):118-124.
12. Simon L, Gauvin F, Amre DK, Saint-Louis P, Lacroix J: Serum procalcitonin and C-reactive protein levels as markers of bacterial infection: a systematic review and meta-analysis. Clinical Infectious Diseases 2004, 39(2):206217.

13. Chan T, Gu F: Early diagnosis of sepsis using serum biomarkers. Expert Review of Molecular Diagnostics 2011, 11(5):487-496.

14. Chacha F, Mirambo MM, Mushi MF, Kayange N, Zuechner A, Kidenya BR, Mshana SE: Utility of qualitative C-reactive protein assay and white blood cells counts in the diagnosis of neonatal septicaemia at Bugando Medical Centre, Tanzania. BMC Pediatrics 2014, 14(1):248.

15. Marková M, Brodská $H$, Malíčková K, Válková V, Cetkovský P, Kolár M, Haluzík M: Substantially elevated C-reactive protein (CRP), together with low levels of procalcitonin (PCT), contributes to diagnosis of fungal infection in immunocompromised patients. Supportive Care in Cancer 2013, 21(10):2733-2742.

16. Hemilä M, Henriksson L, Ylikorkala O: Serum CRP in the diagnosis and treatment of pelvic inflammatory disease. Archives of Gynecology and Oobstetrics 1987, 241(3):177182.

17. Khan F, Malik M, Afzal K, Malik A, Khalid M: Renal biometry and serum c-reactive protein levels in the evaluation of urinary tract infections. Indian J Nephrol 2004, 14:10-14.

18. Honkinen O, Jahnukainen T, Mertsola J, Eskola J, Ruuskanen O: Bacteremic urinary tract infection in children. The Pediatric Infectious Disease Journal 2000, 19(7):630634.

19. Galloway A, Green H, Windsor J, Menon K, Gardner B, Krishnan K: Serial concentrations of C-reactive protein as an indicator of urinary tract infection in $\mathrm{pa}-$ tients with spinal injury. Journal of Clinical Pathology 1986, 39(8):851-855.

20. Nadi HM, Shalan YA, Al-Qatan HY, Alotaibi S: Urinary tract infection in boys less than five years of age: a general pediatric perspective. The Kuwait Medical Journal: KMJ: the official Journal of the Kuwait Medical Association 2006, 38(3):220.

21. Putto A, Meurman O, Ruuskanen O: C-reactive Protein In Viral And Bacterial Infections. Pediatric Research 1985, 19(10):1103-1103.

22. PR M, WL D, GS K, J TJ: Medical microbiology: Tavistock square London. Wolfe Medical Publications Ltd 1990. 
23. Downs SM: Technical report: urinary tract infections in febrile infants and young children. Pediatrics 1999, 103(4):e54-e54.

24. NELSON JD, PETERS PC: Suprapubic aspiration of urine in premature and term infants. Pediatrics 1965, 36(1):132-134.

25. Mshana SE, Kamugisha E, Mirambo M, Chakraborty T, Lyamuya EF: Prevalence of multiresistant gram-negative organisms in a tertiary hospital in Mwanza, Tanzania. BMC Research Notes 2009, 2(1):49.

26. Jorgensen JH, Turnidge JD: Susceptibility test methods: dilution and disk diffusion methods. In: Manual of Clinical Microbiology, Eleventh Edition. American Society of Microbiology; 2015: 1253-1273.

27. Okwara F, Obimbo E, Wafula E, Murila F: Bacteraemia, urinary tract infection and malaria in hospitalised febrile children in Nairobi: is there an association? East African Medical Journal 2004, 81(1):47-51.

28. Batwala V, Magnussen P, Nuwaha F: Antibiotic use among patients with febrile illness in a low malaria endemicity setting in Uganda. Malaria Journal 2011, 10(1):377. 29. Yildiz B, Poyraz H, Cetin N, Kural N, Colak O: High sensitive C-reactive protein: a new marker for urinary tract infection, VUR and renal scar. Eur Rev Med Pharmacol Sci 2013, 17(19):2598-2604.

30. Hooton TM, Besser R, Foxman B, Fritsche TR, Nicolle LE: Acute uncomplicated cystitis in an era of increasing antibiotic resistance: a proposed approach to empirical therapy. Clinical Infectious Diseases 2004, 39(1):75-80.
31. Ayazi P, Mahyar A, Jahani HH, Khabiri S: Urinary tract infections in children. Iran J Pediatr Soc 2010, 2(1):914.

32. Picozzi SC, Casellato S, Mattia Rossini GP, Tejada M, Costa E, Carmignani L: Extended-spectrum beta-lactamase-positive Escherichia coli causing complicated upper urinary tract infection: Urologist should act in time. Urology Annals 2014, 6(2):107.

33. Ladhani S, Gransden W: Increasing antibiotic resistance among urinary tract isolates. Archives of disease in childhood 2003, 88(5):444-445.

34. Yen C, Chen D: Urinary tract infection in children. Journal of microbiology, immunology, and infection= Wei mian yu gan ran za zhi 1999, 32(3):199-205.

35. Naseri M: Alterations of peripheral leukocyte count, erythrocyte sedimentation rate, and C-reactive protein in febrile urinary tract infection. Iran J Kidney Dis 2008, 2(3):137-142.

36. Chan Y-L, Liao H-C, Tsay P-K, Chang S-S, Chen J-C, Liaw S-J: C-reactive protein as an indicator of bacterial infection of adult patients in the emergency department. Chang Gung Medical Journal 2002, 25(7):437-445.

37. Lacour AG, Gervaix A, Zamora SA, Vadas L, Lombard PR, Dayer J-M, Suter S: Procalcitonin, IL-6, IL-8, IL-1 receptor antagonist and C-reactive protein as identificators of serious bacterial infections in children with fever without localising signs. European Journal of Pediatrics 2001, 160(2):95-100. 